\title{
Comprehensive evaluation of meat traits of ducks from two sire strains*
}

\author{
A. Mazanowski ${ }^{1,2}$ and J. Książkiewicz ${ }^{1}$ \\ ${ }^{1}$ Department of Poultry Breeding, National Research Institute of Animal Production \\ Dworzyska 1, 62-035 Kórnik, Poland \\ ${ }^{2}$ Department of Poultry Breeding, University of Technology and Agriculture \\ Mazowiecka 28, 85-084 Bydgoszcz, Poland
}

(Received 29 August 2003; accepted 14 January 2004)

\begin{abstract}
Compared with strain A44, male and female ducks of strain A55 showed significantly higher body weights at 7 weeks of rearing. They did not differ only in shank length and breast muscle thickness. Dressing percentage and percentage of tissue components were similar in both strains. Only the percentage of skin with subcutaneous fat and weight of abdominal fat were lower in A55, which is a favourable result. The weights of breast and leg muscles were found to be positively and significantly correlated with the lengths of trunk with neck, trunk, sternum and shank. The percentage of skin with subcutaneous fat combined with abdominal fat was significantly and negatively correlated with trunk and sternum length and with chest and shank circumference. Trunk and sternum length can be used in selection for high weight of breast and leg muscles and decreased fatness, while shank length can be employed in the selection for decreased fatness. $\mathrm{pH}_{15}$ and $\mathrm{pH}_{24}$ values in strains A44 and A55 were similar to those found in other studies. The water holding capacity of breast and leg muscles was high and higher in A55, whereas the water content of muscles was similar in both strains. Percentages of protein and ash were higher in breast muscles and those of fat in leg muscles. In other Polish and foreign studies the proportions of protein, fat and ash in the muscles were greater. The meat quality of A55 ducks was superior to that of A44 ducks.
\end{abstract}

KEY WORDS: duck, carcass measurements, tissue content, correlation coefficients, chemical components

\footnotetext{
" This work was conducted as part of statutory activity of the National Research Institute of Animal Production, Project No. 1106.2

${ }^{2}$ Corresponding author: e-mail: kiisiel@poczta.onet.pl
} 


\section{INTRODUCTION}

An evaluation of meat traits demonstrated that the optimal age for slaughter of ducks is between 7 and 8 weeks. During that period, the carcass was highest in meat and low in fat, contained small amounts of bones and skin, and the meatto-fat ratio was the most advantageous (Bochno et al., 1984). In order to assess the culinary value of duck meat, $\mathrm{pH}$, water holding capacity and chemical composition of breast and leg muscles (Pingel and Knust, 1977; Knust and Pingel, 1992; Witkiewicz, 2000; Wołoszyn et al., 2002) were determined. Some traits investigated at 7 weeks of age are used as a selection criterion in these ducks (Mazanowski et al., 1999). Carcass tissue composition changes with the age of ducks from the 8th week onwards. Characteristics of genetic parameters, meat traits and chemical composition of meat in 8-week-old ducks of strains A44 and A55 were reported by Mazanowski et al. (2003).

This report presents the results of wide-ranging studies on the meat traits of ducks representing the sire strains A44 and A55. The study was designed to evaluate and compare body measurements, carcass slaughter value, and chemical composition of meat, as well as to determine the correlation coefficients between tissue components and body measurements of ducks from Polish sire strains. The results can be used in breeding work on parental strains of meat ducks.

\section{MATERIAL AND METHODS}

Two strains of meat-type ducks, A44 and A55, were investigated. A44 ducks were selected over 22 years. Strain A55 was obtained by crossing A44 with P8 (Pekins of Danish origin) and 17 consecutive years of selection at the Waterfowl Breeding Farm Dworzyska, belonging to the Research Institute of Animal Production. The offspring of 7-week-old ducks (109 males and 389 females in A44, 162 males and 384 females in A55) were individually weighed to determine the body weight of males and females, separately for each strain. Ducks were fed standard mixtures containing $19.6 \%$ crude protein and $11.96 \mathrm{MJ}$ metabolizable energy (ME) to 3 weeks of rearing and $18.2 \%$ crude protein and $11.73 \mathrm{MJ}$ ME from 4 to 7 weeks.

For dissection, five male and five female offspring were selected from each strain, their weights being close to the strain average for males and females. The birds were tape-measured with an accuracy of $1 \mathrm{~mm}$ for the lengths of trunk with neck, trunk, sternum, shank, chest and shank circumference, and chest depth. The thickness of breast muscles $(4 \mathrm{~cm}$ from the beginning of the keel and $1.5 \mathrm{~cm}$ to the side, parallel to its edge) was measured with a needle probe.

After plucking and cooling for about $20 \mathrm{~h}$, the carcasses were eviscerated, weighed, and dissected into breast and leg muscles, skin with subcutaneous fat, and abdominal 
fat. Dissection was performed following the method of Ziołecki and Doruchowski (1989). Simple correlation coefficients were calculated between the weight of carcass with neck, dressing percentage, weight and percentage of breast and leg muscles, and skin with subcutaneous fat vs body measurements of 7-week-old ducks.

The $\mathrm{pH}$ of breast and leg muscles was determined 15 min post-slaughter $\left(\mathrm{pH}_{15}\right)$ and $20 \mathrm{~h}$ after the carcasses were cooled $\left(\mathrm{pH}_{24}\right)$. Measurements were made with a spearhead electrode linked to a $\mathrm{CP}-401 \mathrm{pH}-$ meter (Elmetron). The electrode was placed at an angle of $45^{\circ}$, midway through the muscles studied. Values of $\mathrm{pH}$ were read from an LCD display with an accuracy of 0.01. Water holding capacity of meat was determined with a modified method of Grau and Hamm (1952). For meat analysis, breast muscles from half the carcass and thigh and lower thigh muscles from one leg were taken during dissection from each bird aged 7 weeks. The meat samples were treated individually. The muscles were ground and mixed in a Cucina HR 283/6 food processor (Philips) to obtain a homogeneous mass. Chemical composition of the breast and leg muscles was determined according to Polish standards $(1975,2000$ a,b,c).

The results were analysed statistically (analysis of variance, evaluation of significant differences, coefficients of correlation) with a package of statistical computer programs developed at the Research Institute of Animal Production (Kiełczewski, 1992).

\section{RESULTS}

Lengths of trunk with neck, trunk and sternum, and chest circumference and depth were significantly higher $(\mathrm{P}<0.05)$ in strain A55 than in A44 (Table 1). Only shank length and breast muscle thickness did not differ between the strains. Significant differences between males and females for body measurements were noted for most of the traits except chest depth and breast muscle thickness. Standard errors of body measurements were low.

Compared with A44, A55 ducks of both sexes showed significantly higher body weights before slaughter and greater weights of eviscerated carcass with neck. Dressing percentage and percentage of tissue components were similar in both strains (Table 2). The only exceptions were the percentage of skin with subcutaneous fat and weight of abdominal fat, which were higher in A44 than in A55. Significant differences were found between males and females for body weight, carcass weight, and leg muscle percentage. Standard errors of meat traits, low for the majority of tissue components, were greater for the weight of eviscerated carcass with neck, body weight and weight of abdominal fat.

Simple correlation coefficients between the weight of eviscerated carcass with neck vs carcass and shank measurements were statistically significant except the 
牙

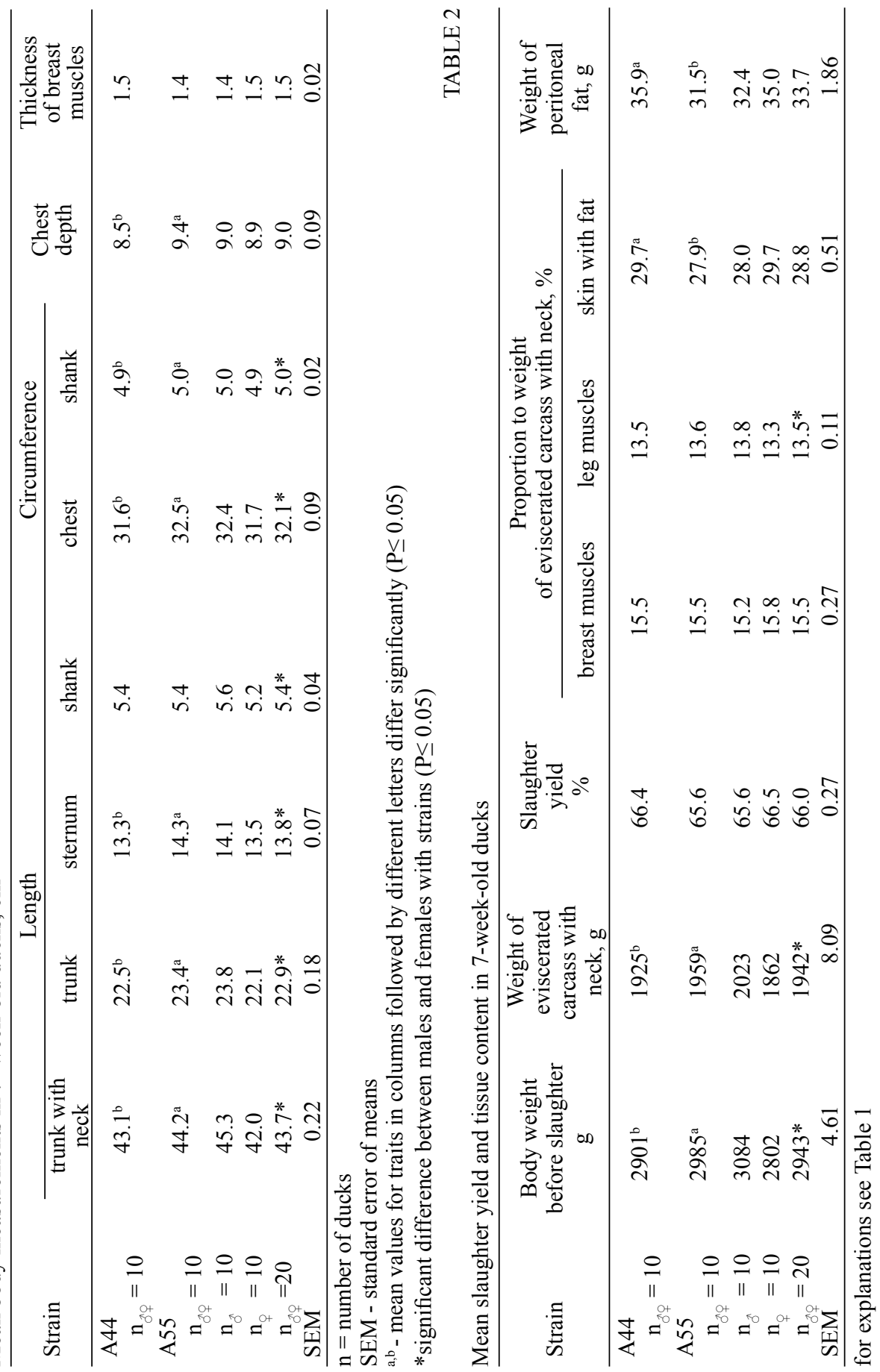


TABLE 3

Coefficients of correlation between traits and body measurements in 7-week-old ducks $(n=20)$

\begin{tabular}{lcccccc}
\hline & \multicolumn{6}{c}{ Traits - correlation coefficients } \\
\cline { 2 - 7 } $\begin{array}{c}\text { Correlated traits } \\
\text { cm }\end{array}$ & $\begin{array}{c}\text { eviscerated } \\
\text { carcass } \\
\text { with neck } \\
\text { g }\end{array}$ & $\begin{array}{c}\text { breast } \\
\text { and leg } \\
\text { muscles } \\
\text { g }\end{array}$ & $\begin{array}{c}\text { skin } \\
\text { with fat } \\
\text { g }\end{array}$ & $\begin{array}{c}\text { slaughter } \\
\text { yield } \\
\%\end{array}$ & $\begin{array}{c}\text { breast } \\
\text { and leg } \\
\text { muscles } \\
\%\end{array}$ & $\begin{array}{c}\text { skin with } \\
\text { fat and } \\
\text { peritoneal } \\
\text { fat, \% }\end{array}$ \\
\hline $\begin{array}{l}\text { Trunk with neck } \\
\text { lenght }\end{array}$ & $0.871^{*}$ & $0.634^{*}$ & 0.075 & -0.208 & 0.013 & -0.401 \\
$\begin{array}{l}\text { Trunk length } \\
\text { Sternum lenght }\end{array}$ & $0.817^{*}$ & $0.665^{*}$ & -0.019 & -0.226 & 0.107 & $-0.468^{*}$ \\
$\begin{array}{l}\text { Shank length } \\
\text { Chest circumference }\end{array}$ & $0.630^{*}$ & $0.536^{*}$ & -0.152 & -0.287 & 0.120 & $-0.506^{*}$ \\
$\begin{array}{l}\text { Shank circumference } \\
\text { Chest depth }\end{array}$ & $0.675^{*}$ & $0.594^{*}$ & 0.165 & -0.022 & -0.034 & -0.195 \\
$\begin{array}{l}\text { Thickness of } \\
\text { breast muscles }\end{array}$ & $0.574^{*}$ & 0.441 & -0.386 & $-0.534^{*}$ & 0.115 & $-0.663^{*}$ \\
\hline $\mathrm{n}=$ number of ducks \\
correlation coefficient statistically significant
\end{tabular}

correlation with chest depth and breast muscle thickness (Table 3). The weight of breast and leg muscles was positively and significantly correlated with the lengths of trunk with neck, trunk, sternum and shank. The weight of skin with subcutaneous fat, dressing percentage, percentage of skin with fat and abdominal fat were found to be negatively correlated with body measurements. Dressing percentage was negatively and significantly correlated only with chest circumference, while the percentage of skin with subcutaneous fat and abdominal fat was negatively and significantly correlated with the lengths of trunk and sternum and with chest and shank circumference. No relationship was detected between tissue components and breast muscle thickness as measured with a needle probe.

The $\mathrm{pH}$ values of ducks' breast muscles did not differ between the strains (Table 4), but in the leg muscles they were significantly higher in A55. Water holding capacity was greater in breast and leg muscles of A55 than A44 ducks, as was the percentage of water, but the difference in breast muscles was statistically significant. The percentage of protein in breast muscles was greater in both strains than in leg muscles, as was the percentage of fat, especially in strain A44. Ash percentage was greater in breast muscles than in leg muscles and was significantly higher in A44. The highest standard errors were noted for water holding capacity of breast and leg muscles. There were no statistically significant differences between 
TABLE 4

Mean $\mathrm{pH}$, water holding capacity and chemical components in breast (BM) and leg (LM) muscles in 7-week-old ducks

\begin{tabular}{|c|c|c|c|c|c|c|c|c|c|c|c|c|c|c|}
\hline \multirow[t]{2}{*}{ Strain } & \multicolumn{2}{|c|}{$\mathrm{pH}_{15}$} & \multicolumn{2}{|c|}{$\mathrm{pH}_{24}$} & \multicolumn{2}{|c|}{$\begin{array}{c}\text { Water } \\
\text { holding } \\
\text { capacity, \% }\end{array}$} & \multicolumn{2}{|c|}{$\begin{array}{c}\text { Water } \\
\%\end{array}$} & \multicolumn{2}{|c|}{$\begin{array}{c}\text { Protein } \\
\%\end{array}$} & \multicolumn{2}{|c|}{$\begin{array}{c}\text { Fat } \\
\%\end{array}$} & \multicolumn{2}{|c|}{$\begin{array}{c}\text { Ash } \\
\%\end{array}$} \\
\hline & $\mathrm{BM}$ & LM & $\mathrm{BM}$ & LM & $\mathrm{BM}$ & LM & $\mathrm{BM}$ & LM & $\mathrm{BM}$ & LM & $\mathrm{BM}$ & LM & $\mathrm{BM}$ & $\mathrm{LM}$ \\
\hline A44 & & & & & & & & & & & & & & \\
\hline$\underset{\mathrm{n}_{\text {ภㅇํ }}}{\mathrm{A} 55}=10$ & 6.0 & $6.0^{\mathrm{b}}$ & 5.9 & $6.0^{\mathrm{b}}$ & $36.2^{\mathrm{a}}$ & $34.0^{\mathrm{a}}$ & $77.2^{\mathrm{b}}$ & 76.9 & 18.9 & 18.8 & 1.6 & $4.7^{\mathrm{a}}$ & $1.4^{\mathrm{a}}$ & 1.1 \\
\hline 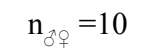 & 6.0 & $6.2^{\mathrm{a}}$ & 5.8 & $6.1^{\mathrm{a}}$ & $31.7^{\mathrm{b}}$ & $30.7^{\mathrm{b}}$ & $77.9^{\mathrm{a}}$ & 77.4 & 19.2 & 18.6 & 1.7 & $3.1^{\mathrm{b}}$ & $1.3^{\mathrm{b}}$ & 1.2 \\
\hline $\mathrm{n}=10$ & 6.0 & 6.1 & 5.9 & 6.1 & 35.0 & 32.7 & 77.7 & 77.4 & 18.8 & 18.7 & 1.6 & 3.6 & 1.4 & 1.2 \\
\hline $\mathrm{n}_{\circ}=10$ & 6.0 & 6.1 & 5.9 & 6.0 & 32.9 & 32.0 & 77.3 & 76.8 & 19.3 & 18.7 & 1.6 & 4.3 & 1.3 & 1.1 \\
\hline $\mathrm{n}_{\delta^{+} \rho}^{+}=20$ & 6.0 & 6.1 & 5.9 & 6.0 & 33.9 & 32.4 & 77.5 & 77.1 & 19.0 & 18.7 & 1.6 & 3.9 & 1.4 & 1.1 \\
\hline SEM & 0.02 & 0.02 & 0.02 & 0.02 & 0.51 & 1.03 & 0.13 & 0.18 & 0.13 & 0.09 & 0.07 & 0.20 & 0.02 & 0.02 \\
\hline
\end{tabular}

males and females in $\mathrm{pH}$ value, water holding capacity, and percentage of meat chemical components.

DISCUSSION

The body weight of 7-week-old ducks was higher in A55 than in A44, similarly as in previous studies (Mazanowski et al., 1999). Equally high body weights were obtained by A44 and A55 hybrids (Mazanowski et al., 2001). A55 ducks were also characterized by greater body dimensions than A44 ducks. The only significant differences between the strains were found in shank length $(5.4 \mathrm{~cm})$ and breast muscle thickness $(1.4-1.5 \mathrm{~cm})$. The dressing percentage was similar in both strains (65.6 and 66.4\%), and results reported elsewhere were only slightly different from the values presented here (Witkiewicz, 2000; Mazanowski et al., 2001). Comparison of two sire strains of similar origin for meat traits was aimed to select the best strain for further breeding.

The percentage of breast muscles is the lowest (15.5\%) in 7-week-old ducks but increases with age, while the percentage of leg muscles declines in each successive week of rearing (Wawro and Brzozowski, 1998; Bons et al., 1999; Mazanowski et al., 2001). In terms of the percentage of skin with subcutaneous fat and of abdominal fat, A44 and A55 ducks did not differ. The weight of abdominal fat in the analysed strains was small (31.5 and $35.9 \mathrm{~g}$ ). Hybrids with A44 and A55 drakes and ducks (Mazanowski et al., 2001) had more abdominal fat in their carcasses $(41.9 \mathrm{~g})$. The content of abdominal fat at 8 weeks of rearing averaged $22 \mathrm{~g}$ 
in strain ducks and two-strain hybrids, $32 \mathrm{~g}$ in A44 ducks of both sexes, and $34 \mathrm{~g}$ in A55 (Książkiewicz, 1993a). The results of selection for increased muscling was good in both strains, and with regard to decreased percentage of skin with fat, it was better in A55 ducks.

In the study by Książkiewicz (1993b), the dressing percentage of 7-week-old A44 and A55 ducks was not significantly correlated with body measurements. In the present trial, a statistically significant and negative correlation was only found between dressing percentage and chest circumference. Książkiewicz (1993b) showed the weight of breast and leg muscles to be significantly and positively correlated with sternum length and breast muscle thickness. In the current study, breast and leg muscles were also found to be positively and significantly correlated with sternum length and with lengths of trunk with neck, trunk and shank.

The correlation coefficients between the weight of skin with subcutaneous fat and body measurements of the ducks were not significant and mostly negative (Książkiewicz and Kontecka, 1993), similarly as in the present trial. Książkiewicz (1993a,b) reported that in 7-week-old A44 ducks, dressing percentage, the percentage of breast and leg muscles, and the weight and percentage of skin with subcutaneous fat were significantly and positively or negatively correlated with chest width, but A55 ducks did not show any correlations between these traits. The weight of skin with subcutaneous fat was not significantly correlated with body measurements, while the percentage of skin with subcutaneous fat combined with abdominal fat was significantly and negatively correlated with trunk and sternum length and chest and shank circumference. Trunk and sternum length can be used in the selection for high weight of breast and leg muscles and for decreased fatness, whereas shank circumference, in selection for decreased fatness.

Post-slaughter $\mathrm{pH}$ values of breast and leg muscles decreased, showing that the process of glycolysis after slaughter took a normal course. In other studies (Pingel and Birla, 1981), the $\mathrm{pH}$ values of breast muscles in 8- and 9-week-old Pekin ducks after slaughter were 5.87 to 6.04 , and $\mathrm{pH}_{24}$ ranged from 5.80 to 5.95, which is similar to the values presented here. Pingel and Knust (1977) found higher $\mathrm{pH}_{24}$ values of breast and leg muscles (6.06 to 7.14) in 7-week-old Pekin ducks than in ducks of the strains reported here. Drip loss in breast muscles of Pekin ducks ranged from 30.0 to $33.8 \%$ (Pingel and Birla, 1981) and was lower than in A44 ducks and higher than in A55 ducks.

The water content in breast muscles was higher in A55 than in A44 ducks, and in leg muscles it was similar in both strains. Percentages of water in breast muscles in 7-week-old ducks of both sexes from breeding strains A44, A55, P66 and P77 ranged from 75.2 to $76.6 \%$ (Witkiewicz, 1998, 2000) and were lower than those reported in the present work. A similar percentage of water in breast muscles (77.7\%) was detected in Pekin ducks by Smith et al. (1993). However, water content in leg muscles was lower. The percentage of protein in breast muscles was 
greater than in leg muscles and similar in both strains. In 7-week-old A44 and A55 ducks of both sexes, the protein content in breast muscles reported by Witkiewicz $(1998,2000)$ was 21.11 and $20.7 \%$, which is higher than in the present work. A greater protein content in breast muscles $(21.5 \%)$ and leg muscles $(22.5 \%)$ was also found in Pekin ducks by Bons et al. $(1998,1999)$. It is likely that the lower protein content in breast muscles of ducks in the present experiment was due to different nutrition with a feed that was lower in protein.

The proportion of fat determined in the present work was lower in breast muscles (1.6-1.7\%) and higher in leg muscles (3.1-4.7\%). The percentage of fat in breast muscles of 7-week-old A44 and A55 drakes and ducks found by Witkiewicz $(1998,2000)$ was lower than that reported here. A higher percentage of fat in breast muscles of ducks (2.3\%) was obtained by Smith et al. (1993). Likewise, Pekin ducks on German farms were characterized by a higher fat content in breast muscles (Pingel and Birla, 1981; Bons et al., 1998). The percentage of ash in this experiment ranged from 1.3 do $1.4 \%$ in breast muscles and from 1.1 to $1.2 \%$ in leg muscles. Bons et al. (1999) noted a higher ash content (1.4\%) in leg muscles of Pekin ducks aged 7 weeks.

\section{CONCLUSIONS}

When compared with A44 ducks, A55 ducks of both sexes showed significantly higher body weights and greater body measurements at 7 weeks of age. Only the percentage of skin with subcutaneous fat and weight of abdominal fat were lower in A55. Based on simple correlation coefficients it was concluded that trunk and sternum length can be used in the selection for high weight of breast muscles and for decreased fatness, and shank circumference in the selection for decreased fatness. The percentages of protein and ash were higher in breast muscles, and those of fat in leg muscles. The greater water holding capacity of breast and leg muscles in A55 ducks indicates that their meat was of better quality than in A44 ducks.

\section{REFERENCES}

Bochno R., Lewczuk A., Wawro E., Mazanowski A., 1984. Growth rate of particular tissue components of ducks' carcasses (in Polish). Prz. nauk. Lit. Zoot. 30 (3-4), 113-117

Bons A., Timmler R., Jeroch H., 1998. Changes in body composition and content of fat and protein in carcass of male and female Pekin ducks during growth. Zesz. Nauk. Prz. hod. 36, 165-175

Bons A., Timmler R., Jeroch H., 1999. Changes in body composition and crude nutrient content of pekin ducks growth. Proceedings of the $1^{\text {st }}$ World's Waterfowl Conference, Taichung (Taiwan), pp. 328-332 
Grau R., Hamm R., 1952. Eine einfache Methode zur Bestimmung der Wasserbindung im Fleisch. Fleischwirtschaft 4, 295-297

Kiełczewski K., 1992. Package of Statistical Computer Programs. National Research Institute of Animal Production, Zakrzewo (Poland)

Knust U., Pingel H., 1992. The effect of initial pH-value in duck breast and thigh muscle on other meat characteristics. Proceedings of the $19^{\text {th }}$ World's Poultry Congress, Amsterdam (The Netherlands) 3, pp. 221-224

Książkiewicz J., 1993a. Relationship between the tissue content and some carcass dimensions of duck with English and native origin (in Polish). Zesz. Nauk. Drob. COBRD Poznań (Poland) $8,57-65$

Książkiewicz J., 1993b. Indices of carcass breast muscle and leg content in two breeding strains of ducks. Rocz. Nauk. Zoot. 20 (2), 65-75

Książkiewicz J., Kontecka H., 1993. A characteristics of dependence between body weight, body measurements and carcass tissue composition of Mini-Duck, Orpington and duck with different content of Khaki Campbell (in Polish). Rocz. AR Pozn. 246, 45-56

Mazanowski A., Kisiel T., Gornowicz E., 2003. Carcass quality, meat traits and chemical composition of meat in ducks of paternal strains A44 and A55. Anim. Sci. Pap. Rep. 21, 251-263

Mazanowski A., Książkiewicz J., Kisiel T., 1999. Reproductive traits of ducks from paternal strains in two laying periods and meat traits of their offspring. Ann. Anim. Sci. - Rocz. Nauk. Zoot. 26, 205-217

Mazanowski A., Książkiewicz J., Kisiel T., 2001. Evaluation of meat traits in four strain crossbred ducks (in Polish). Rocz. Nauk. Zoot. 28 (1), 25-43

Pingel H., Birla M., 1981. The effect of antemortem factors on the carcass quality of waterfowl (in Polish). Research Institute of Animal Production, Department of Poultry Breeding 9, 121-126

Pingel H., Knust U., 1997. Review on ducks meat quality. Proceedings of the $11^{\text {th }}$ European Symposium on the Quality of Poultry Meat, Tours (France), pp. 26-38

Polish Norm. PN-75/A-04018, 1975. Nitrogen assay according Kjeldahl method and correction for crude protein (in Polish)

Polish Norm. PN-ISO 936, 2000a. Meat and meat products. Total ash assay (in Polish)

Polish Norm. PN-ISO 1442, 2000b. Meat and meat products. Water content assay (in Polish)

Polish Norm. PN-ISO 1444, 2000c. Meat and meat products. Free fat assay (in Polish)

Smith D.P., Fletcher D.L., Buhr R.J., Byer R.S., 1993. Peckin duckling and broiler chicken Pectoralis muscle structure and composition. Poultry Sci. 72, 202-208

Wawro K., Brzozowski W., 1998. The effect of age and sex on the muscle deposition in ducks. Anim. Sci. Pap. Rep. 16 (2), 113-123

Witkiewicz K., 1998. Comparison of ducks from two breeding strains with regard to some selected live and slaughter traits (in Polish). Rocz. AR Pozn. 302, 243-251

Witkiewicz K., 2000. Zoometric measurements, slaughter value and chemical composition of the breast muscle in two strains of ducks of Pekin type (in Polish). Rocz. AR Pozn. 330, 231-240

Wołoszyn J., Książkiewicz J., Orkusz A., Skrabka-Błotnicka T., Biernat J., Kisiel T., 2002. Preliminary evaluation of chemical composition of duck's muscles from two Polish conservative flocks. Proceedings of the $48^{\text {th }}$ Iternational Congress of Meat Science and Technology, Rome (Italy), pp. 374-375

Ziołecki J., Doruchowski W., 1989. Methods of Evaluation Poultry Slaughter Value (in Polish). COBRD Editor, Poznań, pp. 1-22 


\section{STRESZCZENIE}

\section{Kompleksowa ocena cech mięsnych kaczek z dwóch rodów ojcowskich}

Kaczki obojga płci z rodu A55 w porównaniu z ptakami z rodu A44 miały w 7. tygodniu odchowu statystycznie istotnie większą masę ciała; nie różniły się tylko długością skoku i grubością mięśni piersiowych. Wydajność rzeźna oraz procentowe udziały składników tkankowych były w obydwóch rodach podobne. Procentowa zawartość skóry z tłuszczem podskórnym i masa tłuszczu sadełkowego były tylko mniejsze w A55, co jest cechą dodatnią.

Stwierdzono dodatnie i statystycznie istotne korelacje między masą mięśni piersiowych i nóg a długością tułowia z szyja, tułowia, mostka i skoku. Procentowy udział skóry z tłuszczem podskórnym łącznie z tłuszczem sadełkowym był statystycznie istotnie ujemnie skorelowany z długością tułowia i mostka oraz obwodem klatki piersiowej i skoku. W selekcji na dużą masę mięśni piersiowych i nóg oraz zmniejszenie otłuszczenia można wykorzystać długość tułowia i mostka, a w selekcji na zmniejszenie otłuszczenia obwód skoku.

Wartości odczynu $\mathrm{pH}_{15}$ i $\mathrm{pH}_{24}$ były w mięsie ptaków z rodów A44 i A55 podobne do uzyskanych w innych badaniach. Wodochłonność mięśni piersiowych i nóg była duża i większa w A55, a udział wody w mięśniach kaczek z obydwóch rodów był podobny. Procentowy udział białka i popiołu był większy w mięśniach piersiowych, a tłuszczu w mięśniach nóg. W innych badaniach krajowych i zagranicznych udział w mięśniach piersiowych i nóg białka, tłuszczu i popiołu był przeważnie większy.

Jakość mięsa kaczek z rodu A55 była lepsza niż z A44. 